\title{
Meraih Mutu Sekolah Melalui Data Mutu: Suatu Tinjauan
}

\author{
Nurmaini MY \\ Pengawas Sekolah Utama Dinas Pendidikan Provinsi Jambi \\ Email: nurmaininur739@yahoo.com
}

\begin{abstract}
Increasing quality education is responsibility of all stake holders, but the one that most probably demanded to have big responsibity is the principal of the school. Principal must know what to do to improve their school better. Internal and external quality assurance contain quality data. Internal and external quality data is significant to grow the school beter. The problem is most principal don't use these data in improving their schools. To meet client satisfaction, school must develop school continuously. Internal data in internal quality assurance System (SPMI) can be used to develop school as well as external data of quality assurance ( SPME / accreditation) to meet SNP because Internal quality assurance ( SPMI) aims to help school develop their program and avoid the gaps between ideal condition and fact based on school self evaluation. Cycling procedure owned by SPMI make the development of school suit to its needs (Stating the standard as National Standard, mapping school condition for finding weakness and stenghthness, plan and conduct the plan, montoring and audit). Following this cycles make schools reach proper improvement. Other quality data is external data which can also be used by principal to improve its school because this data contains recommendation to meet SNP after assessed by assessor. Thus all principal make use both of internal and external quality data to achieve school quality.
\end{abstract}

Keywords: quality assurance system, internal quality data, external quality data

\section{PENDAHULUAN}

Peningkatan mutu pendididkan di semua jenjang pendidikan dasar dan menengah merupakan tujuan yang harus dicapai oleh semua sekolah dan pemerintah karena mutu merupakan kata kunci dalam pendidikan, sukar memisahkan mutu dengan pendidikan karena satu sama lainnya saling berkait ibarat dua mata uang. Mutu merupakan tujuan akhir sebuah penyelenggaraan pendidikan, sementara pendidikan membutuhkan kata mutu untuk perolehan kualitas. Hal ini sejalan dengan diterbitkannya Undang-Undang Nomor 20 tahun 2003 tentang Sistem Pendidikan Nasional serta diluncurkannya Peraturan Pemerintah no 19 tahun 2005 tentang Standar Nasional Pendidikan yang kemudian diubah menjadi PP 32 tahun 2013 tentang peruhal yang sama. Pada standar tersebut dapat dilihat bahwa pemerintah sudah menetapkan standar yang berlaku secara nasional tentang kedelapan standar ; tersebut, standar isi, SKL, standar proses, standar penilaian, standar pendidik dan tenaga kependidikan, standar sarpras, standar pengelolaan, standar pembiayaan, standar penilaian. Semua undang-undang dan peraturan pemerintah tersebut mengacu jelas kepada wujuda nyata dari program peningkatan mutu.

Dunia pendidikan khususnya pendidikan dasar dan menengah saat ini dihadapkan pada persoalan rendahnya mutu pendidikan. Berdasarkan survey United Nations Educational Scientific and Cultural Organization ( UNESCO ), menyatakan bahwa perkembangan pendidikan di wilayah Asia Pasifik untuk Indonesi menduduki peringkat 10 dari 14 negara yang disurvey. Sedangkan index pembangunan pendidikan atau Education Development Index ( EDI ) berdasarkan data tahun 2008 adalah 0.934. Nilai itu menempatkan Indonesia pada posisi 69 dari 127 negara di dunia. Hasil akreditasipun tidak menunjukan capaian yang amat baik, BAN S/M mengatakan bahwa hasil akreditasi pada tahun 2017 masih dominan dengan nilai B. Masih banyak sekolah ynag berakreditasi $\mathrm{C}$ dan bahkan belum terakreditasi (http:bansm.kemdikbud.go.id. 8 Maret 2019). Tentu perlu upaya peningkaan mutu. Sistem
Penjaminan sangat diperlukan dalam menjaga kestabilan dan atau peningkatan mutu. Terdapat dua sitem penjaminan mutu yaitu SIstem Penjaminan Mutu Eksternal (SPME) dan Sistem Penjaminan Mutu Internal (SPMI). Keduanya saling berkontribusi mengawal sekolah berada dalam koridor mutu ynag jelas dan melakukan pengembangan sekolah yang jelas juga. SPMI merupakan pembenahan diri sendiri melalui analisis kekuatan dan kelemahan, memberikan kontribusi positif terhadap SPME. Sebaliknya SPME yang kredibel akan menjamin mutu pendidikan dasar dan menengah serta tentuny ahasil-hasil SPME dapat dimanfaatkan untuk peningkatan mutu sekolah. Kegiatan pengumpumpulan data ddilakuan pemerintah dengan berbagai strategi antara lain Evaluasi Diri, Setifikasi, PADATI dan EMIS serta Ujian Nasional dan Monitoring Sekolah oleh Pemerintah Daerah. Pencapaian mutu tersebut sudah merupakan tugas bersama kepala sekolah, guru, pemerintah dan stake holder lainnya. Kedua sistem penjaminan mutu eksternal maupun internal memiliki data mutu. Data mutu SPME merupakan hasil laporan visitasi oleh asesor lengkap dengan analisis komprehensif yang dilakukan asesor dan rekomendasi per standar bahkan per indikator. Data mutu SPMI merupakan rapor mutu yang berasal dari evaluasi diri seklah secara internal, dan memiliki analisis kekuatan dan kelemahan dari kondisi sekolah yang sebeanarnya. Sekolah dapat merefleksikan dirinya dengan melihat kelebihan dan kekurangan masingmasing indikator pada SNP. Pada tulisan ini penulis membatasi data mutu yang didiskusikan disini adalah data mutu pada akreditasi sekolah dan data mutu yang ada pada SPMI.

Sistem Penjaminan Mutu Internal (SPMI) yang merupakan sistem penjaminan mutu pendidikan mencakup seluruh aspek penyelenggaraan pendidikan dengan berbagai sumber daya mencapai SNP. Satuan pendidikan melakukan siklus dalam sistem penjaminan mutu secara mandiri dan berkesinambungan hingga terbangun budaya mutu pada satuan pendidikan. Budaya mutu akan mendorong satuan pendidikan untuk 
meningkatkankan mutu pendidikan secara terus menerus sehingg a berujung pada peningkatan mutu secara konsisten dari waktu ke waktu secara bertahap hingga dipenuhinya standar yang telah ditetapkan atau mungkin melampaui standar. Data mutu yang terkandung SPMI merupakan analisis kekuatan dan kelemahan menuju mutu.

Tolok ukur mutu pada sekolah menengah adalah terpenuhinya indikator mutu pada semua Standar Nasional Pendidikan. Standar Nasional Pendidikan yang menjadi pedoman mutu adalah Standar Kelulusan, Standar Isi, Standar Proses, Standar Tendik, Standar Sarana Prasrana, Standar Pengelolaan, Standar pembiayaan dan Standar Penilaian ( SNP : 2013 )

Pemenuhan terhadap kedelapan standar nasional tersebut akan memenuhi kepuasaan pelanggan serta tentunya sebagai tolokm iukur tercapainya mutu pendidikan.Mutu pendidikan di jenjang dasar dan menengah diukur dari status capaian SNP satuan pendidikan.

\section{Permasalahan}

Permasalahannya adalah apakah sekolah sudah memanfaatkan data mutu yang ada pada penjaminan mutu internal maupun eksternal ini dalam pengembangan sekolahnya? Jawabannya belum. Hal ini data mutu yang ada pada SPMI tidak diolah sekolah apalagi dijadikan patokan atau pijakan untuk menumbuhkembangkan budaya mutu yang berwujud dengan mutu pendidikan. Masing-masing satuan pendidikan memiliki data mutu yang terhimpun melalui PMP (Pemetaan Mutu Pendidikan). PMP yang dilengkapi secara jujur dan komprehensih akan menjadi evaluasi diri ynag kredibel, sehingga dapat menjadi pijakan bagi satuan pendidikan untuk menaganilis kekuatan dan kelemahan meliputi indikator-indikator yang ada dalam 8 SNP tersebut. Rapor mutu akan memberikan informasi ketercapaian masing -masing standar bahkan per indikatornya. Pengembangan sekolah dapat dilakukan berbasis pada data mutu yang ada sehingga program yang dibuat oleh satuan pendidikan match dengan kebutuhannya. Permasalahan yang sering terjadi adalah program yang ada pada satuan pendidikan tidak didasarkan kepada data mutu sehingga tidak sesuai dengan kebutuhan sekolah, misalnya ketika kepala sekolah memutuskan untuk mengadakan workshop RPP, hal ini bisa saja tidak sesuia dengan keebutuhan karena secara data yang dibutuhkan oleh guru bukanlah RPP tetapi penilaian hasil belajar. Sekolah dapat mengetahui kebutuhannya tersebut melalui data mutu yang ada pada system penjaminan mutu internal tersebut.

Begitupun hasil akreditasi, data mutu yang ada pada akreditasi belum termnafaatkan karena hasil akreditasi tidak menjadi konsumsi sekolah. Sekolah hanya mendapatkan laporan atau rekap nilai akreditasi tanpa mengetahui hasil capaian mereka ketika divisitasi.

Untuk itu perlu digaris-bawahi bahwa sekolah harus menyadari kekuatan dan manfaat dari data mutu dari SPMI dan SPME dalam pencapaian mutu pendidikan di satuan pendidikan. Setiap sekolah khususnya Tim Penjaminan Mutu Pendidikan Sekolah (TPMPS) harus melakukan analisis mutu sehinga melakhirkan program yang sesuai dengan kebutuhan masing-masing standarnya.

Pemanfaatan data mutu pada penjaminan mutu internal dan eksternal merupakan upaya yang dapat ditempuh sekolah untuk menumbuhkembangkan budaya mutu yang selanjutnya menghasilkan mutu pendidikan. Tetapi permasalahannya adalah bagaiaman mutu dapat diraih melalui pemanfataan data mutu pada penjaminan mutu internal dan eksternal dalam bentuk data mutu akreditasi pada Satuan Pendidikan?

Tulisan ini bertujuan untuk memberikan gambaran atau gagasan tentang pemanfaatan data mutu pada Sisten penjaminan Mutu Internal dan Eksternal seperti data mutu akreditasi dalam rangka meraih mutu pendidikan pada sekolah menengah atas.

\section{Data Mutu}

Sebelum bicara soal data mutu perlu dibahas dulu pengertian mutu khususnya mutu pendidikan. Mutu dapat berarti kualitas, tingkat, derajat, kadar. Mutu bahkan sering ditafsirkan beragam tergantung sudut pandang masing-masing. Menurut Juran (1993) mutu pendidikan ialah kecocokan penggunaan produk (fitness for us) untuk memenuhi kebutuhan dan kepuasan pelanggan. Kecocokan pengguna produk tersebut didasarkan atas lima ciri:

1. teknologi yaitu kekuatan

2. Psikologis yaitu rasa atau status

3. Waktu yaitu kehandalan

4. Kontraktual yaitu jaminan

5. Etika yaitu sopan santun

Selanjutnya Deming (1982) mendefinfikan mutu adalah kesesuain dengan kebutuhan pasar atau konsumen. Perusahaan yang bermutu ialah perusahaan yang menguasai pasar karena hasil produksinya sesuai dengan kebutuhan konsumen, sehingga menimbulkan kepuasan bagi konsumen, jika konsemen merasa puas. Hal lain dari definisi mutu adalah sesuai standar, sesia harapan pelanggan, dan sesuia yang dijanjikan (Kemdikbud: 2016)

Selanjutnya Kemendikbud (2016) menyatakan mutu pendidikan dasar dan menengah adalah tingkat kesesuaian antara penyelenggaraan pendidikan dasar dan menengah dengan Standar Nasional Pendidikan. Jelas mutu diartikan dengan pemenuhan kepuasan pelanggan, sebuah sekolah dikatakan bermutu bila mampu memberikan layanan sesuai kebutuhan dan kepuasaan pelanggan, dalam hal ini sesuia dengan standar yang berlaku.

Berdasarkan uaraian di atas yang penulis maksud dengan mutu pada tulisna ini adalah kondisi yang sesuia dengan standar.Mutu pendidikan pada satuan pendididkan tidak akan meningkat tanpa diiringi dengan penjaminan mutu baik internal maupun eksternal.

Data mutu berkaitan erat dengan SPMI sebagai evaluasi internal sekolah. Peningkatan mutu pendidikan tidak akan banyak berarti jika tidak dikawal oleh SPMI. Data dan informasi dalam sistem penjaminan mutu digunakan untuk:

1. memantau dan mengevaluasi tingkat ketercapaian Standar Nasional Pendidikan pada satuan pendidkan dan / atau program keahlian ;

2. Memantau dan mengevaluasi tingkat ketercapaian 
Standar Nasional Pendidikan;

3. Acuan pelaksanaan akreditasi satuan pendidikan. ( Kemdikbud : 2016 )

Penerapan penjaminan mutu pendidikan di sekolah akan memastikan bahwa pengelolaan sekolah, proses pembelajaran dan program-program lainnya dijalankan sesuai mutu.

\section{Komponen Penjaminan Mutu}

Penjaminan mutu merupakan hal penting yang sudah diatur dalam undang-undang, seperti pada Peraturan pemerintah No 19 tahun 2005 tentang SNP menjelaskan bahwa tujuan SNP adalah menjamin mutu pendidikan secara nasional. Sebagai tindak lanjut dari tujuan di atas maka pada sekolah menengah dikenal dengan adanya Sistem Penjaminan Mutu Internal (SPMI) dan Sistem Penjaminan Mutu Eksternal ( SPME ). Kedua sistem penjamian mutu ini berfungsi sebagai "quality control" mutu pendidikan pada jenjang pendidikan dasar dan pendidikan menengah.

Sistem Penjmaminan Mutu pada pendidikan Dasar dan menengah adalah suatu kesatuan unsur yang terdiri atas organisasi, kebijakan, dan proses terpadu yang mengatur segala kegiatan untuk peningkatan mutu pendidikan secara berkesinambungan (Kemdikbud: 2016). Sistem Penjaminan Mutu pada sekolah dasar dan menengah sangat diperlukan karena berfungsi sebagai penggendali penyelenggaraan pendidikan oleh satuan pendidikan untuk mencapai mutu.

Sistem penjaminan mutu dimaksud dapat dikategorikan menjadi dua yaitu Sistem Penjaminan Mutu Internal (SPMI) dan Sistem Penjaminan Mutu Eksternal (SPME). Tujuan kedua komponen ini sama yaitu menjamin pemenuhan standar pada satuan pendidikan dasar dan menengah secara sistemik, holistic, dan berkelanjutan, sehingga tumbuh dan berkembang budaya mutu pada satuan pendidikan secara mandiri. Adapun perbedaaan antara SPMI dan SPME adalah Sistem Penjaminan Mutu Internal adalah sistem penjaminan mutu yang dijalankan oleh satuan pendidikan dan seluruh komponen satuan pendidikan. Sementara Sistem Penjamian Mutu Eksternal adalah sistem penjaminan mutu yang dijalankan oleh oleh pemerintah, pemerintah daerah, lembaga akreditasi, dan lembaga stndarisasi pendidikan.

Berdasarkan uraian di atas penulis garis bawahi bahwa data mutu yang didiskusikan pada artikel ini data mutu yang ada pada SPMI dan data mutu yang ada pada Akreditasi.

\section{Data Mutu SPMI}

Penjaminan mutu internal dilakukan oleh satuan pendidikan. Adapun siklus yang dapat dilalui sebagai berikut:

1. Penetapan Standar, memiliki standar mutu sebagai landasan dalam melaksanakan pejmainan mutu pendidikan, Sesuai dengan UU No 20 tahun 2003, SNP adalah kriteri aminimal dalam menyelenggarakan pendidikan. Satuan Pnedidikan dapat menetapkan staandar di atas SNP apabila penyelenggaraan pendidikan telah memenuhi seluruh criteria dalam SNP.

2. Pemetaan mutu
Sekolah meemtakan mutu pendidikan berdasarkan standar mutu ynag telah ditetapkan melalui evaluasi diri sekolah yang menghasilkan peta mutu (capaian standar), masalah yang dihadapai dan rekomendasi.

3. Penyusunan Rencana pemenuhan

Sekolah membuat rencana pemenuhan mutu berdasarkan hasil pemetaan mutum, dokumen kebijakan, pendidikan pada level nasional, daerah dan satuan pendidikan serta rencana strategis pengembangan satuan pendidikan. Hasil perencanaan dituangkan dalam dokumen perncanaan satuan pendidikan serta rencana aksi kegiatan.

4. Pelaksanaan Pemenuhan

Sekolah melaksanakan pemenuhan berdasarkan rencana yang sudah dibuat sehingga standar dapat tercapai.

5. Evaluasi / Audit Mutu

Melakukan pengendalian terhadap proses pelaksanaan pemenuhan mutu yang telaha dilakukan sesuia dengan perencanaan yang disusun untuk menjamin kepastian terjadinya peningkatan mutu yang berkelanjutan.

\section{Data Mutu Eksternal Akreditasi}

Akreditasi sebagai penjaminan mutu eksternal memilki data mutu. Sebelum lanjut dilihat dulu pengertian akreditasi. Akreditasi berasal dari bahasa Inggris yaitu "to accredite "yang artinya adalah meniulia kelayakan teknis / akademis suatu lembaga penyelenggara program pendidikan tertetnu untuk menghasilkan lulusan dengan spesifikasi kompetensi yang telah ditetapkan. Akreditasi sekolah atau madrasah merupakan penilaian yang menyeluruh terhadap sekolah sebagai bentuk akuntabilitas public (Kemendikbud: 2017). Dikatakan menyeluruh karen akreditasi menilai kelayakan sebuah sekolah /madrasah pada semua standar 8 dari 8 Standar Nasional Pendidikan.

Badan Akreditasi Nasional (BAN) Sekolah / Madrasah melakukan analisis data ketika melakukan akreditasi, otomatis akreditasi memiliki data mutu berupa perangkat instrument ynag sudah diverifikasi, catatan temuan visitasi dan rekomendasi perbaikan. (Kemendikbud: 2017). Data mutu ini diisi dengan prinsipprinsip kejujuran, objektif, efektif, komprehensif, mandiri, berbasis kesiapan (Permendikbud No 13: 2018).

Adapun ruang lingkup akreditasi meliputi: TK / RA, TKLB, SD/MI, SMP / MTs, SMPLB, SMA / MA, SMK/ MAK, dan SMA LB baik sekolah negri maupun swasta.

Manfaat Data Mutu Sebagai kontrol mutu eksternal (salah satu bagian dari SPME) tentu akreditasi memberikan manfaat yang signifikan bagi sekolah/ madfasah. Manfaat tersebut antara lain:

1. Membantu sekolah / madrasah dalam menentukan dan mempermudah kepindahan peserta didik dari suatu sekkolah ke sekolah lain, pertukaran guru, dan kerjasama yang saling menguntungkan. (Misalnya, sekolah yang berakreditasi $A$ hnaya dapat menerima siswa pindah dari sekolah yang berarkreditasi $A$.

2. Membantu mnegidentifikasi sekolah / madrasah dan program dalam rangka pemberian bantuan oleh pemerintah, swasta, atau donatur lainnya.

3. Acuan dalam peningkatan mutu sekolah / madrasah 
dan rencana pengembangan sekolah / madrasah.

4. Umpan balik dari SPMI sekolah sebagai sebuah hasil kerja keras sehingga dorongan baagi guru untuk selalu meningkatkna diri..

5. Motivator agar sekolah dapat meningkatkna mutu pendidikan secara bertahap, terencana, dan kompetitif baik tingkat kabupaten, provinsi, nasional dan bahkan internasional.

6. Sebagai data mutu sekolah baik bagi sekolah, pemerintah dan masyarakat dalam rangka peningkatan mutu.

7. Bagi siswa dapat meningkatkan kepercayaan diri bahwa mereka dapat pendidikan yang layak. (Kemdikbud: 2016)

\section{Pembahasan}

Sebagaimana yang dipaparkan sebelumnya bahwa data mutu internal pada SPMI memiliki manfaat yang banyak sekali demi kelangsungan sekolah. Data mutu yang ada pada penjaminan mutu internal berasal dari sekolah dan diisi oleh warga sekolah secara komprehensif, tentu saja data ini merupakan cermin bagi sekolah atau madrasah. Sekolah melakukan evaluasi diri terhadap kodisi sekolahbnya. Tentu saja manfaat dari evaluasi diri ini snagat banyak antara lain; mengetahui kekurangan dan kelebihan sekolah. Hal ini tentu sangat bermanfaat bagi sekolah untuk menyusun program pengembangan ke depan. Tidak banyak sekolah yang menyadari akan pentingnya evaluasi diri ini, kebanyakan sekolah berasumsi dirinya sudah maapn dan tidak perlu dievaluasi. Akibatnya adalah sekolah tidak pernah mengenal dirinya, termasuk kekurangan dan kelebihannya.

Penerapan SPMI dalam bentuk evaluasi diri sekolah akan menjamin pencapaian budaya mutu. SPMI terdiri dari beberapa siklus seperti yang dipaparkan pada bab sebelumnya, diawali dengan; evaluasi diri, menganalisis kekuatan dan kelemahan, menyusun rekomendasi untuk menghasilkan program kerja, melaksanakan program kerja, memonitor dan mengevaluasi. Rangkaian kegiatan merupakan satu yang bila diterapkan akan memberikan damapak yang sangat signifikan karena peningkatan muotu ataupun pebcapaian budaya mutu akan lebih bermakna bila dilakukan secara otonomi.

"Quality assurance should be internally driven, institutionalized within each organization's standard procedure, and could involve external parties. However, since quality improvement is also a concern of all stake holders, quality improvement should aim at producing quality outputs and outcomes as a part of public accountability," ( Pranata : 2010 http://www.guru99.com, 20 Feb 2019).

Pelaksanaan penjaminan mutu oleh satuan pendidikan yang dilakukan secara otonomi dengan MBS akan memberikan dampak yang baik untuk peningkatan mutu atau penanaman budaya mutu. Selanjutnya, hal ini juga akan membantu sekolah memiliki menejemen data yang baik. Hanya saja tidak banyak sekolah menyadari penting memiliki menejemen data yang baik. Hasilnya kebanyakan sekolah tidak memiliki data yang lengkap terhadap menejemen sekolahnya. Kecendrungan kepala sekolah kepada tindakan tanpa melengkapai tindakan dengan data yang lengkap dan bahkan program yang ada dalam Rencana Kerja Sekolah pada umunya tidak didasarkan pada evaluasi diri.

Suatu hal yang keliru dilakukan kepala sekolah adalah tidak merumuskan program berdasarkan evaluasi diri. Tentu saja program yang dirumuskan atau dicantumkan pada RKS tersebut tidak menyentuh kebutuhannya sekolah. Misal, tiba-tiba di awal semester kepala sekolah menggelar In House Training (IHT) tentang Pelaksanaan Pembelajaran Aktif. Semua guru ikut kegiatan. Ternyata rapor mutunya menyatakan bahwa yang dibutuhkan guru bukan pembelajaran aktif melainkan membelajarkan siswa menguasai kompetensi berfikir kritis, dan bila mau jujur banyak sekali ketimpangan-ketimpangan yang dilakukann satuan pendidikan dalam menyusun program sekolah karena tidak berbasis data mutu. Contoh di atas mengilustrasikan betapa analisis kekuatan dan kelemahan pada instrument rapor mutu itu sangat bermakna dilakukann untuk menjawab kebutuhan satuan pendidkan. Ada delapan standar yang terdiri dari beberapa indikator mutu dan kemudian diturunkan menjadi sub indikator mutu. Sungguh suatu kekeliruan besar bila tidak melaksanakan penjaminan mutu dan bila tidak menggunakan data mutu pada SPMI.

SPMI akan mengawal pengembangan sekolah berdasarkan kebutuhan, karena SPMI memiliki siklus yang dilakukan secara berkesinambunag. Diawali dengan penetapan standar mutu yaitu capaian SNP, kemudian sekolah melakukan pemetaan mutu melalui evaluasi diri sekolah. Ini yang tidak disadari oleh sekolah dan bahkan ada sekolah yang tidak pernah melaksanakan evaluais diri. Setelah mengetahui kelemhan baru disusun program Evaluasi diri menghasilkan analisis kekuatan dan kelebihan dari rapor mutu didasarkan pada Pemetaan Mutu Pendidikan (PMP) yang setiap tahunnya diisi oleh komponen terkait seperti siswa, TAS, komite, pengawas, guru dan kepala sekolah. rapor mutu ynag baik akan menghasilkan analisis yang baik yang seterusnya dapat menjadi koridor pengawal pengembangan sekolah. Setelah diketahui kelemahan baru direncanakn dan dilakukan pemenuhannya, Pemenuhanpun dilaksankan berbasis control audit dan monitoring. Alangkah indahnya siklus ini kala diterapkan oleh sekolah.

Satuan pendidikan kita tidak terbiasa menerapkan penjaminan mutu pendidkan melalui evaluasi diri dengan rapor mutu seperti yang didiskusikan di atas. Sementara di Negara-negara maju penjaminan mutu pendidikan selalu ada. Inggris misalnya menerapkan "Supported School Self-Evaluation (SSSE) merupakan instrument utama yang digunakan sekolah untuk mengevaluasi dirinya sebelum merumuskan program kerja. Deborah (2000) "School self-evaluation now sits alongside, an dhas been embraced by, external inspection as a major mechanism for monitoringand raising standards of achievement in school". Artinya sekolah melaksanakan EDS bersama pengawas untuk meningkatkan mutu dan standard sekolah.

Hal lain yang merupakan peranan dari SPMI ini adalah pelaksanaan program yang dirumuskan tidak semuanya menjadi tanggung jawab satuan pendidikan. 
Sub indikator pada rapor mutu cukup komprehensifi karena mengakomodir 8 SNP yang mungkin saja pengembangan programnya tidak menjadi tanggung jawab sekolah, semisal pengembanagan sarana dan prasarana, yang dapat diusulkan pengembangannya oleh sekolah kepada pihak terkiat. Sekolah dapat mengusulkan kepada pemangku kepentingan terkait tentang pemenuhan standar tadi. Satuan pendidikan bisa merekomendasikan program kegiatan kepada Dinas terkait, komite dan dunia industri dan dunia usaha yang ada di sekitas satuan pendidikan. Otomatis, MBS ini akan melibatkan unsur-unsur terkait secara maksimal.

Sebagaimana yang dipaparkan sebelumnya bahwa pengembangan dengan menggunakan SPMI dilakukan secara bersiklus. Hal ini akan membuat program dan kegiatan pengembangan yang dibuat sekolah menjadi lebih matang dan terprogram. Siklus demi siklus yang dilewati merupakan proses proses pematangan dalam rangka pengembangan sekolah sesuai kebutuhan ril yang ada.Dengan demikian SPMI memiliki banyak peranan dalam meningkatkan mutu sekolah. Pemenuhan standar dengan analisis yang tepat membuat peningkatan mutu semakin signifikan bagi capaian yang harus diraih sekolah. Data mutu pada SPMI sangat memungkinkan sekolah memanfaatkannya melaui MBSnya kepala sekolah. Proses yang bersiklus sangat memungkinkan sekolah merencanakan perbaikan secara bertahap. Analisis data mutu dari rapor mutu merupakan evaluasi diri sekolah yang sangat bermanfaat untuk mengenal kekuatan dan kelemahan sebagai pijakan memulai sebuah perbaikan. Seandainya semua sekolah melakukan evaluasi diri dari SPMI ini tentu hasilnya adalah sekolah memiliki arah yang jelas untuk perbaikan diri. Pengembangan sekolah yang tidak berdasar kepada analisis data mutu akan menghasilkan pengembangan salah sasaran, sangat tidak efektif untuk peningkatan mutu. Kepala sekolah harus menyadari manfaat dari analisis mutu dengan evaluasi diri pada SPMI ini. Analisis tidak saja tentang kelemahan dan kelenihan tetapi lengkap dengan penyebab masalahnya. Hal ini sangat memnbantu sekolah untuk merekomendasikan program selanjutnya.

Sebagai yang dipaparkan di atas analisis yang jelas menghasilkan rekomendasi. Beberapa program lengkap dengan waktu pelaksanaan, penanggung jawab dan satuan biaya dapat dirumuskan dan dicantumkan dalam RKS. Hasilnya adalah sekolah bakal memiliki program yang sesuai dengan kondisi dan kebutuhannya karena dirumuskan dari analisis kekuatan dan kelemahan kondisi yang ada.

Kalau semua sekolah memanfaatkan data mutu internal dalam SPMI otomatis mutu pendidikan atau satuan pendidikaan juga dapat meningkat. Perlu peranan pihak terkait seperti pengawas untuk memfasilitasi terjadinya pemanfaatan data internal secara terstruktur. LPMP hanya memiliki sekolah projek dengan jumlah terbatas. Desiminasi dilakukan oleh pihak sekolah model kepada sekolah imbas. Hanya saja proses desiminasi kurang terkontrol sehingga los sasaran. Perlu pengawasan dari pengawasan pembina satuan ketika desiminasi dilaksanakan, dan perlu juga target yang jelas dari desiminasi sekolah model kepada sekolah imbasnya. Pengawas Pembina dapat melakuan pembimbingan lanjutan untuk desiminasi ini. Artinya perlu satu ketegasan dan arahan yang tega sebagai kepala sekolah dalam melakukan analisis internal. Disamping itu, kepala sekolh harus menyadari peranannya bahwa perolehan mutu tidak dapat dipisahkan dari peranannya dan kepala sekolah memegang peranan strategis dalam peraihan mutu. Proses imbas yang dilakukan sekolah model akan memperbanyak sekolah sadar dengan manfaat data mutu dalam pencaian mutu pendidikan di satuannya.

Selanjutnya data mutu eksternal seperti data akreditasi, data ini memiliki manfaat yang banyak sekali bagi kelangsungan sebuah sekolah atau satuan pendidikan. Saat ini persaingan sekolah atau satuan pendidikan semakin ketat, masyarakat sangat selektif dengan predikat akreditasi sekolah. Publik sudah cukup paham dengan pengakuan yang dikeluarkan oleh BAN / SM/ Masyarakat cendrung menyekolahkan anaknya di sekolah yang berakreditasi A atau amat baik. Dengan demikian terjadi persaingan anatar sekolah dan saling membenahi diri, agar dapat memberikan kepuasan kepada kliennya.

Terjadinya tuntutan mutu terhadap lulusan yang berkualitas memaksa sekolah / madrasah meningkatkan mutu dengan membenahi komponen akreditasi: 1). Standar Kelulusan; 2). Standar isi; 3). Standr Proses; 4). Standar Tendik; 5). Standar Sarpras; 6). Standar Pengelolaan; 7). Standar Pembiayaan; 8). Standar Penilaian. Hasil akreditasi member manfaat kepada siswa, sekolah dan guru antara lain:

1. Sebagai acuan bagi pengembangan sekolah dalam upaya peningkatan mutu.

2. Bahan masukan untuk memberdayakan dan mengembangkan warga sekolah.

3. Bahan informasi untuk pemetaan indikator keberhasilan kinerja warga sekolah.

4. Dorongan bagi guru untuk selalu meningkatkan diri dari bekerja keras untuk memberi layanan yang terbaik.

5. Bagi masyarakat, hasil akreditasi merupakan informasi yang akurat dalam menentukan pilihan terhadap sekolah yang berkualitas.

6. Bagi Dinas Pendidikan, hasil akreditasi akan menjadi dasar pembinaan dan pengembangan dalam rangka peningkatan mutu sekolah.

7. Bagi pemerintah, pengembangan sistem akreditasi di masa mendatang serta bahan infromasi tentang kualitas sekolah di Indonesia.

Berapapa poin di atas menggambarkan bahwa hasil akreditasi bagi mutu sekolah. Tetapi tidak banyak sekolah yang menyadari akan manfaat ini. Pada umumnya akreditasi berakhir ketika proses visitasi selesai dilaksanakan. Tidak banyak sekloah bahkan tidak ada sekolah yang menyadari bahwa data mutu yang ada pada akreditasi tersebut berisikan manfaat yang luar biasa. Otomatis data mutu tersebut bisa digunakan untuk meraih mutu. Data mutu apa saja yang ada pada akreditasi? Akreditasi memiliki instrument pengumpul data dari 8 SNP secara komprehensif. Instrumen yang sudah diisi oleh asesor merupakan data atau informasi tentang foro sekolah ketika diakreditasi. Selanjutnya asesor memberikan catatan pertemuan 
berikut dengan rekomedsi masing-masing indikator setiap standar berisikan masukan bagi sekolah, Dinas Pendidikan dan Pemerintah Pusat dan masyarakat. Rekomendasi tersebut merupakan perbaiakn yang harus dilakukan sekloah untuk mencapai mutu.

Data mutu ini dapat dimanfaatkan oleh pihak sekiolah untuk peningkatan mutu karena data mutu tersebut memiliki informasi yang handal tentang foto sekolah yang sebenarnya yang dilakukan oleh pihak eksternal. Tentu data yang diinformasikan pada data mutu ini berisi data-data oibjektif. Tetapi, kebanyakan sekolah tidak memperoleh data mutu paska visitasi, rata-rata keputusan. Sekolah atau madrasah tidak pernah meminta instrumen, catatan dan rekomendasi dari asesor. BAN S/M pun tidak menginformasikan data mutu tersebut kepada pihak sekolah sungguhpun sekolah dengan hasil akreditasi cukup atau kurang ataupun baik sebenarnya sangat mengharapkan data mutu tersebut. Data mutu yang ada pada catatan visitasi adalah dokumen perbaikan mutu yang sebenarnya dapat dipakai sekolah untuk memperbaiki mutu berdasarkan informasi dari data mutu akreditasi tersebut.

Berdasarkan uraian di atas, jelas bahwa akreditasi sekolah berperan sebagai pengawasan eksternal dalam rangka perbaikan mutu karena analisis yang dilakukan selama penilaian sangat bersifat komprehensif meliputi 8 SNP dengan beberapa indiukator yang komprehensif. Data mutu dari perangkat akreditasi merupakan informasi berharga yang sangat dibutuhkan sekolah dalam mempertbaiki diri ke depan.

Mutu pendidikan atau satuan pendidikan merupakan tanggung jawab bersama warga sekolah, masyarakat dan pemerintah. Peningkatan kualitas pendidikan sangat menekankna pentingnya peranan kepala sekkolah sebagai pelaku utama yang otonom, disamping peranan orang tua murid dan pemerintah. Konsep peningkatakan mutu berbasis MBS memberikan peluang bagi kepala sekolah untuk memainkan peranannya dalam proses peraihan mutu. Mutu pendidikan pada satuan pendidikan dapat diraih melalui : 1.) Pemanfaatan data mutu internal ; dan 2) Pemanfaatn data mutu eksternal (akreditasi). Kedua komponen ini termasuk sistem penjaminan mutu internal dan eksternal.

Setelah pemanfaatan data internal, data yang dapat dipakai untuk meraih mutu adalah data evalausi eksternal seperti data mutu akreditasi. Data eksternal ini tidak kalh penting dengan data mutu internal. Data mutu eksternal seperti catatan dan rekomendasi akreditasi merupakan alat untuk mencapai mutu pendidikan. Data mutu eksternal tersebut seharusnya dikases sekolah begitu selesainya proses visitasi.Sekolah dapat berbenah dengan memanfaatkan data mutu teersebut. Bila data mutu eksternal dimanfaatkan dengan cermat oleh sekolah maka tidak mustahil capaian mutu dapat diperoleh dangan baik.

Mengakhiri tulisan ini dapat disimpulkan bahwa data mutu internal dan data mutu eksternal sangat berkontribusi meningkatkan mutu satuan pendidikan bilaaa sekolah menafaatannya dengan cermat. Kedua data mutu tersebut memiliki keunggulan yang luar baisa untuk dimanfatkaduanya memiliki 8 SNP sebagai acuan mutu. Permasalahannya adalah punya niatkah kepala sekolah untuk meningkatkan mutu secara terprogram?

\section{SIMPULAN}

1. Data mutu internal dan eksternal dalam bentuk data SPMI dan data akreditasi dapat meningkatkan mutu pendidikan pada satuan pendidikan.

2. Kepala sekolah dapat memulai peningkatan mutu dengan memanfaatkan data pada rapor mutu secara bersiklus dan bertahap menganalisis dan merumuskan program kegiatan sampai pelaksanaan program dan pemantaauan.

3. Kepala sekolah juga dapat memanfaatkan hasil akreditasi sebagai data mutu eksternal karena pada akreditasi ditemukan rekomendasi terhadap sekolah yang divisitasimasukan untuk perbaikan SNP .

\section{DAFTAR PUSTAKA}

Abdul haris dan Nurhayati, 2010, Menejemen Mutu Pendidikan, Alfabetha, Bandung.

Anonim, 2005, Standards and Guidelines for Quality Assurance in Tejh European Higher Education, Helsinki, Findland.

Deborah and Rudd, 2000, Evaluating School Self Evaluation, National association of Eduactional Reseach, London.

Juknis Pelaksanaan Penjaminan Mutu Satuan Pendidikan, 2010, Kemdikbud, Jakarta.

Naskah Akademik Rancangan Permendikbud tentang Penjaminan Mutu Pendidikan Dasar dan Menengah, 2010, Kemdikbud Jakarta.

Peraturan Menteri Pendidikan Nasional No. 63 tahun 2009 tentang SPMP, Kemdikbud, Jakarta.

Permendikbud No 13 Tahun 2018 tetang BAN S/M, Kemdikbud, Jakarta.

Kemdikbud, 2017, Juklak PMP, Jakarta. Peraturan Pemerintah 19 Tahun 2005 diubah menjadi No 32 Tahun 2013 tentang Standar Nasional Pendidikan

Undang-Undang Republik Indonesia No 20 Tahun 2003 tentang Sistem Pendidikan Nasioanal. http://www.guru99.com, 20 Feb 2019

http:bansm.kemdikbud.go.id. 28 Februari 2019 http://miftah19.word.press.com 7 Maret 2019 http://steemit.com7 Maret2019 